\title{
Effects of Intercropping with Post-Grafting Generation of Galinsoga parviflora on Photosynthesis of Lettuce under Cadmium Stress
}

\author{
Kewen Huang ${ }^{1, a}$, Lijin Lin ${ }^{2, b}$ and Ming'an Liao ${ }^{1, c *}$ \\ ${ }^{1}$ College of Horticulture, Sichuan Agricultural University, Chengdu, Sichuan, China \\ ${ }^{2}$ Institute of Pomology and Olericulture, Sichuan Agricultural University, Chengdu, Sichuan, China \\ a263733029@qq.com, bllj800924@qq.com, Iman@sicau.edu.cn \\ ${ }^{*}$ Corresponding author. Kewen Huang and Lijin Lin contributed equally to this work.
}

Keywords: Lettuce; Intercropping; Photosynthesis; Galinsoga parviflora

\begin{abstract}
The pot experiment was conducted to study the effects of intercropping with positive and negative grafting generations of two ecotypes (farmland and mining) of cadmium (Cd) hyperaccumulator plants Galinsoga parviflora on photosynthesis of lettuce. The positive grafting: the rootstock was mining ecotype of G. parviflora (post generation was defined as mining-rootstock) and the scion was farmland ecotype of $G$. parviflora (post generation was defined as farmlandscion); the negative grafting: the rootstock was farmland ecotype of $G$. parviflora (post generation was defined as farmland-rootstock) and the scion was mining ecotype of G. parviflora (post generation was defined as mining- scion). The results show that, compared with the monoculture of lettuce, only Intercropping with mining-scion significantly increased the chlorophyll $a$, chlorophyll $b$ and total chlorophyll contents of lettuce. In addition, the photosynthetic rate (Pn), stomatal conductance $(\mathrm{Gs}), \mathrm{CO}_{2}$ concentration of intercellular $(\mathrm{Ci})$ and transpiration rate $(\mathrm{Tr})$ of lettuce all significantly increased by Intercropping with mining-scion and reached maximum in all treatments. Therefore, Intercropping with mining-scion could improve the photosynthesis of lettuce under $\mathrm{Cd}$ stress.
\end{abstract}

\section{Introduction}

Cadmium $(\mathrm{Cd})$ is one of the most toxic heavy metals which is not easy to degrade in nature, with a high bioaccumulation coefficient [1]. The long-term accumulation of $\mathrm{Cd}$ in soil would affect the photosynthesis of plants, and even reduce the yield of economic crops [2-4]. Studies have shown that appropriate intercropping can change the distribution of light in the population, thereby increasing the plant's absorption and conversion of light [5]. Lettuce is an annual or biennial herb that is rich in nutrients and has a high food value [6]. However, the chlorophyll content of lettuce was significantly reduced under high Cd stress, which resulted in the decrease of photosynthesis [7]. Galinsoga parviflora is a widely distributed $\mathrm{Cd}$ hyperaccumulator that grows rapidly and has a strong vitality [8]. The study found that there are certain differences in the accumulation characteristics of $\mathrm{Cd}$ between the mining ecotype $G$. parviflora and the farmland ecotype $G$. parviflora [9]. A preliminary study of this experiment found that the absorption of $\mathrm{Cd}$ in the post-grafting generations of the two ecotypes $G$. parviflora were significantly different. In view of this, this experiment intercropped lettuce with post-grafting generation of G. parviflora, and studied the effect of intercropping on the photosynthetic characteristics of lettuce, in order to screen post-grafting generation of $G$. parviflora that can improve the photosynthesis of lettuce.

\section{Materials and Methods}

Materials collection. The seeds of mining ecotype $G$. parviflora and farmland ecotype $G$. parviflora were respectively collected from Tangjiashan lead-zinc mine $\left(29^{\circ} 24^{\prime} \mathrm{N}, 102^{\circ} 38^{\prime} \mathrm{E}\right)$ and farmland of Ya'an campus farm of Sichuan Agricultural University $\left(30^{\circ} 23^{\prime} \mathrm{N}, 103^{\circ} 48^{\prime} \mathrm{E}\right.$ ) in September, 2015, stored at $4{ }^{\circ} \mathrm{C}$. The Tangjiashan lead-zinc mine locates in Hanyuan County, Sichuan Province, China, with an typical dry-hot valley climate. The farm of Sichuan Agricultural 
University locates in Yucheng County, Sichuan Province, China, with an humid subtropical monsoon climate.

Lettuce variety for Italy Resistant to Hot-Breaked Lettuce, purchased in JIEYANG BANGFENG SEED CO. , LTD.

Grafting. In October 2015, the two ecotypes of G. parviflora seeds were grown at a temperature of $25{ }^{\circ} \mathrm{C}$, illumination of $4000 \mathrm{~lx}$ and air humidity of $80 \%$. When the seedlings of G. parviflora height was about $3 \mathrm{~cm}$ and 2 pieces of true leaves unfolded, transplanted into cadmium-free pots. After the G. parviflora height was about $10 \mathrm{~cm}$, two ecological types of $G$. parviflora were grafted positively and negatively. (1) Un-grafted of farmland ecotype (post generation was defined as farmland). (2) Un-grafted of mining ecotype (post generation was defined as mining). (3) The postive grafting: the rootstock was farmland ecotype of G. parviflora (post generation was defined as farmland-rootstock) and the scion was mining ecotype of $G$. parviflora (post generation was defined as mining-scion). (4) The negative grafting: the rootstock was mining ecotype of $G$. parviflora (post generation was defined as mining-rootstock) and the scion was farmland ecotype of $G$. parviflora (post generation was defined as farmland-scion). All of the leaves of the rootstocks remained.The grafting method was cleft method. And the plastic band with a width of about $1 \mathrm{~cm}$ and a length of $20 \mathrm{~cm}$ was used for binding. Watering after grafting and keeping the soil moisture content was maintained at $80 \%$ of field capacity, and covering it with a mulching film and shade net. After 10 days, the mulching film and the shade net were gradually removed, and the tied plastic band was removed. When grafting treatments were completed, all $G$. parviflora were transplanted into cadmium-free pots, and collected the post generation seeds.

Experimental Design. The experiment was conducted in Chengdu Campus of Sichuan Agricultural University. In February 2016, after the cadmium-free soil was air-dried and crushed, $2.5 \mathrm{~kg}$ soil was weighed into each plastic pot $(21 \mathrm{~cm}$ high, $20 \mathrm{~cm}$ in diameter). Soaking uniformly by $10 \mathrm{mg} / \mathrm{kg} \mathrm{Cd}$ (in the form of $\mathrm{CdCl}_{2} \cdot 2.5 \mathrm{H}_{2} \mathrm{O}$ ) solution for 4 weeks. All pots were watered each day to keep the soil moisture about $80 \%$. In March 2016, the post-grafting generations of G. parviflora were grown at a temperature of $25^{\circ} \mathrm{C}$, illumination of $4000 \mathrm{~lx}$ and air humidity of $80 \%$. When the seedlings of $G$. parviflora height were about $3 \mathrm{~cm}$ and 2 pieces of true leaves unfolded, transplanted into Cd soil to intercrop with lettuce. 7 treatments were conducted: (1) monoculture of lettuce, (2) lettuce intercropped with farmland, (3) lettuce intercropped with mining, (4) lettuce intercropped with farmland-rootstock, (5) lettuce intercropped with mining-rootstock, (6) lettuce intercropped with farmland-scion, (7) lettcue intercropped with mining-scion. Intercropping treatments were planted with 3 lettuces and $1 \mathrm{G}$. parviflora. Monoculture treatments were planted 4 lettuces. Four replicates per treatment and the pots placed completely random. The distance between pots was $15 \mathrm{~cm}$, and the pot position exchanged aperiodically to weaken the impact of the marginal effects. The soil moisture content was maintained at $80 \%$ of field capacity until the plants were harvested. After 60 days, the photosynthesis of each lettuce was determined by using LI-6400 portable photosynthesis meter (LI-COR Inc., USA) in June 2016. The photosynthetic parameters of the photosynthesis meter were manual control $\mathrm{CO}_{2}$ concentration $400 \mu \mathrm{mol} / \mathrm{mol}$, temperature $30{ }^{\circ} \mathrm{C}$, light intensity $1000 \mu \mathrm{mol} / \mathrm{m}^{2} / \mathrm{s}$. The determination of photosynthetic parameters were net photosynthetic rate $(\mathrm{Pn})$, transpiration rate $(\mathrm{Tr})$, stomatal conductance $(\mathrm{Gs}), \mathrm{CO}_{2}$ concentration of intercellular $(\mathrm{Ci})$ and value of pressure deficit leaf ( $\mathrm{Vpdl})$. And then, the upper mature leaves of lettuce were collected to determine the photosynthetic pigment contents (chlorophyll $a$, chlorophyll $b$, total chlorophyll and carotenoid) [10].

Statistical Analyses. Statistical analyses were conducted using SPSS 13.0 statistical software (IBM, Chicago, IL, USA). Data were analyzed by one-way analysis of variance with least significant difference (LSD) at the $\mathrm{p}=0.05$ confidence level.

\section{Results and Discussion}

Photosynthetic Pigment Content in Lettuce. Compared to monoculture, only Intercropping with 
mining-scion significantly increased the chlorophyll $a$, chlorophyll $b$ and total chlorophyll contents of lettuce by $5.57 \%(p<0.05), 7.26 \%(p<0.05), 5.80 \%(p<0.05)$, respectively, and other treatments had little effect. For carotenoid content of lettuce, Intercropping with mining and Intercropping with farmland-scion significantly increased the carotenoid content of lettuce by $30.56 \%(p<0.05)$ and $25.00 \%(p<0.05)$ respectively compared to monoculture.

Table 1 Photosynthetic pigment content in lettuce

\begin{tabular}{|c|l|l|l|l|}
\hline \multicolumn{1}{|c|}{ Treatments } & $\begin{array}{c}\text { Chlorophyll } a \\
(\mathrm{mg} / \mathrm{g})\end{array}$ & $\begin{array}{c}\text { Chlorophyll } b \\
(\mathrm{mg} / \mathrm{g})\end{array}$ & $\begin{array}{c}\text { Total chlorophyll } \\
(\mathrm{mg} / \mathrm{g})\end{array}$ & $\begin{array}{c}\text { Carotenoid } \\
(\mathrm{mg} / \mathrm{g})\end{array}$ \\
\hline Monoculture & $0.790 \pm 0.013 \mathrm{ab}$ & $0.124 \pm 0.005 \mathrm{ab}$ & $0.914 \pm 0.018 \mathrm{ab}$ & $0.072 \pm 0.004 \mathrm{~cd}$ \\
\hline Intercropping with farmland & $0.768 \pm 0.032 \mathrm{ab}$ & $0.124 \pm 0.011 \mathrm{ab}$ & $0.892 \pm 0.043 \mathrm{ab}$ & $0.078 \pm 0.010 \mathrm{bcd}$ \\
\hline Intercropping with mining & $0.766 \pm 0.016 \mathrm{ab}$ & $0.121 \pm 0.001 \mathrm{ab}$ & $0.887 \pm 0.017 \mathrm{ab}$ & $0.094 \pm 0.006 \mathrm{a}$ \\
\hline Intercropping with farmland-rootstock & $0.730 \pm 0.040 \mathrm{~b}$ & $0.113 \pm 0.006 \mathrm{~b}$ & $0.843 \pm 0.046 \mathrm{~b}$ & $0.066 \pm 0.003 \mathrm{~d}$ \\
\hline Intercropping with mining-rootstock & $0.701 \pm 0.004 \mathrm{~b}$ & $0.114 \pm 0.001 \mathrm{~b}$ & $0.815 \pm 0.005 \mathrm{~b}$ & $0.085 \pm 0.002 \mathrm{abc}$ \\
\hline Intercropping with farmland-scion & $0.758 \pm 0.092 \mathrm{ab}$ & $0.120 \pm 0.010 \mathrm{ab}$ & $0.878 \pm 0.102 \mathrm{ab}$ & $0.090 \pm 0.001 \mathrm{ab}$ \\
\hline Intercropping with mining-scion & $0.834 \pm 0.009 \mathrm{a}$ & $0.133 \pm 0.001 \mathrm{a}$ & $0.967 \pm 0.010 \mathrm{a}$ & $0.080 \pm 0.008 \mathrm{abc}$ \\
\hline
\end{tabular}

Values are means \pm standard errors. Means with the same letter within each column are not significantly different at $p<0.05$.

Table 2 Photosynthetic characteristics of lettuce

\begin{tabular}{|c|c|c|c|c|c|}
\hline Treatments & $\begin{array}{c}\mathrm{Pn} \\
(\mu \mathrm{mol} \\
\left.\mathrm{CO}_{2} / \mathrm{m}^{2} / \mathrm{s}\right)\end{array}$ & $\begin{array}{c}\mathrm{Gs} \\
(\mathrm{mol} \\
\left.\mathrm{H}_{2} \mathrm{O} / \mathrm{m}^{2} / \mathrm{s}\right)\end{array}$ & $\begin{array}{c}\mathrm{Ci} \\
(\mu \mathrm{mol} \\
\left.\mathrm{CO}_{2} / \mathrm{mol}\right)\end{array}$ & $\begin{array}{c}\mathrm{Tr} \\
(\mathrm{mmol} \\
\left.\mathrm{H}_{2} \mathrm{O} / \mathrm{m}^{2} / \mathrm{s}\right)\end{array}$ & $\begin{array}{c}\mathrm{Vpdl} \\
(\mathrm{kPa})\end{array}$ \\
\hline Monoculture & $16.15 \pm 0.067 \mathrm{~b}$ & $0.272 \pm 0.034 \mathrm{~b}$ & $277.6 \pm 0.034 \mathrm{~b}$ & $3.413 \pm 0.134 \mathrm{~b}$ & $1.333 \pm 0.123 \mathrm{a}$ \\
\hline $\begin{array}{c}\text { Intercropping with } \\
\text { farmland }\end{array}$ & $15.65 \pm 0.032 \mathrm{~d}$ & $0.251 \pm 0.323 \mathrm{~d}$ & $273.5 \pm 0.023 \mathrm{~d}$ & $2.804 \pm 0.143 \mathrm{c}$ & $1.312 \pm 0.982 \mathrm{a}$ \\
\hline $\begin{array}{c}\text { Intercropping with } \\
\text { mining }\end{array}$ & $11.06 \pm 0.043 \mathrm{f}$ & $0.183 \pm 0.174 \mathrm{f}$ & $267.5 \pm 0.014 \mathrm{f}$ & $2.214 \pm 0.014 \mathrm{~d}$ & $1.254 \pm 0.042 \mathrm{~b}$ \\
\hline $\begin{array}{c}\text { Intercropping with } \\
\text { farmland-rootstock }\end{array}$ & $8.75 \pm 0.012 \mathrm{~g}$ & $0.202 \pm 0.223 \mathrm{e}$ & $265.5 \pm 0.013 \mathrm{~g}$ & $1.883 \pm 0.033 \mathrm{e}$ & $1.152 \pm 0.034 \mathrm{c}$ \\
\hline $\begin{array}{c}\text { Intercropping with } \\
\text { mining-rootstock }\end{array}$ & $12.83 \pm 0.012 \mathrm{e}$ & $0.173 \pm 0.214 \mathrm{~g}$ & $269.3 \pm 0.024 \mathrm{e}$ & $1.734 \pm 0.094 \mathrm{e}$ & $1.084 \pm 0.012 \mathrm{~d}$ \\
\hline $\begin{array}{c}\text { Intercropping with } \\
\text { farmland-scion }\end{array}$ & $16.07 \pm 0.033 \mathrm{c}$ & $0.264 \pm 0.313 \mathrm{c}$ & $277.0 \pm 0.033 \mathrm{c}$ & $3.685 \pm 0.033 \mathrm{a}$ & $0.953 \pm 0.063 \mathrm{e}$ \\
\hline $\begin{array}{c}\text { Intercropping with } \\
\text { mining-scion }\end{array}$ & $16.24 \pm 0.024 \mathrm{a}$ & $0.305 \pm 0.014 \mathrm{a}$ & $296.9 \pm 0.024 \mathrm{a}$ & $3.733 \pm 0.053 \mathrm{a}$ & $0.952 \pm 0.014 \mathrm{e}$ \\
\hline
\end{tabular}

Values are means \pm standard errors. Means with the same letter within each column are not significantly different at $p<0.05$.

Photosynthetic Characteristics of Lettuce. Under Cd stress, the Pn and Ci of lettuce were ranked in the following order: Intercropping with mining-scion $>$ Monoculture $>$ Intercropping with farmland-scion $>$ Intercropping with farmland $>$ Intercropping with mining-rootstock $>$ Intercropping with mining > Intercropping with farmland-rootstock. Compared to monoculture, in addition to Intercropping with mining-scion significantly increasted the Gs of lettuce other treatments all significantly reduced it. For the Tr of lettuce, Intercropping with farmland-scion and Intercropping with mining-scion significantly increased the $\operatorname{Tr}$ of lettuce by $7.97 \%(p<0.05)$ and $9.38 \%(p<0.05)$ respectively compareted to monoculture. And with the exception of Intercropping with farmland, all other treatments significantly reduced Vpdl of lettuce compared to monoculture. 


\section{Conclusions}

Under Cd stress, Intercropping with mining-scion could significantly improve the chlorophyll a, chlorophyll $\mathrm{b}$ and total chlorophyll contents of lettuce, compared to monoculture. Besides, the Pn, Gs, $\mathrm{Ci}$ and $\mathrm{Tr}$ of lettuce all significantly increased by Intercropping with mining-scion and reached maximum in all treatments. Therefore, Intercropping with mining-scion could improve the photosynthesis of lettuce under cadmium stress.

\section{Acknowledgements}

This work was financially supported by the Application Infrastructure Project of Science and Technology Department of Sichuan Province (2016JY0258).

\section{References}

[1] Z.N. Teng, B.H. Fang, Y. Liu, Y. He, J. Yang, X.E. He and Y.Z. Zhang: Chinese Journal of Agrometeorology Vol. 37(2016), p. 538.

[2] S.J. Feng, T.X. Yang, Y.J. Zhang, X.J. Lü, Z.S. Liu and A.Z. Wei: Journal of Agro-Environment Science Vol. 32(2013), p. 539.

[3] G.W. Sun, Z.J. Zhu, X.Z. Fang, R.Y. Chen and H.C. Liu: Plant Nutrition and Fertilizer Science Vol. 11(2005), p. 700.

[4] W.D. Cheng, H.G. Yao, G.P. Zhang, M.L. Tang and D. Peter: Scientia Agricultura Sinica Vol. 38(2005), p. 528.

[5] N.Y. Jiao, T.Y. Ning, M.K. Yang, G.Z. Fu, F. Yin, G.W. Xu and Z.J. Li: ACTA ECOLOGICA SINICA Vol. 33(2013), P. 4324.

[6] China Flora Editorial Board: Flora Reipublicae Popularis Sinicae (Science Press, Beijing, China 1997)

[7] J. Xu, B.H. Hu, T. Ge and Q. Chen: Hubei Agricultural Sciences Vol. 53(2014), p. 4892.

[8] L.J. Lin, Q. Jin, Y.J. Liu, B. Ning, M.A. Liao and L. Luo: Environmental Toxicology and Chemistry Vol. 33(2014), p. 2422.

[9] Y.T. Cao, X.H. Peng, Q. Lei and L.J. Lin: Shaanxi Journal of Agricultural Sciences Vol. 61(2015), p. 61.

[10]Z.B. Hao, J. Chang and Z. Xu: Plant Physiology Experiment (Harbin Institute of Technology Press, China 2004). 